\title{
Information provision, policy support, and farmers' adaptive responses against drought: An empirical study in the North China Plain
}

\author{
Jinxia Wang ${ }^{\mathrm{a}, *}$, Yu Yang ${ }^{\mathrm{a}, \mathrm{b}}$, Jikun Huang ${ }^{\mathrm{a}}$, Kevin Chen $^{\mathrm{c}}$ \\ a Center for Chinese Agricultural Policy, Institute of Geographic Sciences and Natural Resources Research, Chinese Academy of Sciences, Jia, No. 11, Datun \\ Rd, Anwai, Beijing 100101, China \\ ${ }^{\mathrm{b}}$ University of Chinese Academy of Sciences, Beijing 100049, China \\ ${ }^{\mathrm{c}}$ International Food Policy Research Institute, Beijing Office, No. 12, Zhongguancun South Street, Haidian District, Beijing 100081, China
}

\section{A R T I C L E I N F O}

\section{Article history:}

Available online 6 January 2015

\section{Keywords:}

Farm management measures

Determinants

Wheat

Drought

North China Plain

\begin{abstract}
A B S T R A C T
As an important agricultural production region in China, the North China Plain (NCP) is an ecologically vulnerable region that frequently is hit by drought. Faced with drought and other extreme climate events, policy makers have given top priority to the formulation and implementation of adaptation policies. This paper assessed the effectiveness of adaptation policies, including the provision of early warning information and policy supports, on farmers' adaptive decisions regarding the planting of the wheat crop in the NCP. Based on a unique dataset from a large-scale village and farm survey in five provinces in the NCP, an econometric model of farmers' adaptation practices is estimated. Results show that when faced with a more severe drought, farmers change their management practices to mitigate its effects by adjusting seeding or harvesting dates and enhancing irrigation intensity. The provisions of early warning and prevention information and policy supports against drought facilitate farmers to make farm management adaptations. However, the effectiveness of early warning and prevention information or policy supports differs by their provision channels or types. The findings of this study have policy implications in coping with the rising frequency and seriousness of extreme weather events in China as a whole and in ecologically more vulnerable NCP in particular.
\end{abstract}

(c) 2015 Elsevier B.V. All rights reserved.

\section{Introduction}

As an important agricultural production region in China, North China Plain (NCP) is one of the ecologically vulnerable regions frequently hit by drought. The NCP is a large alluvial plain developed by intermittent flooding of the Huang, Huai and Hai rivers (Thomson et al., 2006). Seventy-five-percent of China's wheat, 32\% of maize, and $19 \%$ of rice are supplied by the farmlands of the NCP (NSBC, 2012). Despite its importance to China's food security, sustainable development of this region has been challenged by frequent and severe drought disasters. In the past three decades (1980-2011), on average, about 7.4 million ha of crop areas per year in the NCP has suffered the effects of drought. In 2000, losses attributed to drought were as high as 13 million ha, with half of the crops suffering yield losses of more than 30\% (MWR, 2012). The drought caused large socio-economic losses, which amounted to

\footnotetext{
* Corresponding author. Tel.: +86 10 64889841; fax: +86 1064856533.

E-mail address: jxwang.ccap@igsnrr.ac.cn (J. Wang).
}

1.4 billion USD in 2008 (MWR, 2009). Not only does drought impact agricultural production, it also degrades the region's ecological system, as evidenced by its dried up rivers, declining groundwater table, deteriorated water quality, and disturbed riparian habitats (Xia et al., 2004; Mishra and Singh, 2010). Future climate change promises to increase the severity and frequency of droughts (IPCC, 2007; Mishra and Singh, 2010; Dai, 2011).

Research results show that taking appropriate adaptive measures are essential to mitigate some negative impacts of drought on agricultural production. For example, Zhang et al. (2011) found that implementing comprehensive adaptive measures in the field (such as changing varieties, adjusting seeding and/or harvesting dates, implementing precision irrigation approaches, and applying other farm management measures) decreased yield loss due to drought by $15 \%$ in the NCP. As summarized by the IPCC (2012), in the event of a $1-2{ }^{\circ} \mathrm{C}$ increase in the local temperature, changing crop varieties, modifying seeding and/or harvesting dates, and applying other farm management measures can reduce yield losses by $10-15 \%$. Tian et al. (2014) pointed out that farmers can compensate for the negative influence of climate warming or even increase 
crop yield by choosing the most suitable crops, cultivars and cropping systems. The effectiveness of adaptive measures for drought mitigation and the management of other climate-related risks has been studied by some scholars (Kantolic et al., 2007; Di Falco et al., 2011; Xiao and Tao, 2014).

Frequent droughts and their resulting negative impacts on the $\mathrm{NCP}$ region have concerned policymakers, who question how they may mitigate these impacts through appropriate adaptive measures. In recent years, both international and domestic policymakers have accorded top priority to formulating and implementing adaptation policies in their respective policy agendas (World Bank, 2010; IPCC, 2012). In addition to issuing white papers on national adaptation policies, China also has introduced some specific policies on coping with droughts (NDRC, 2007, 2012). For example, the Chinese government issued the Drought Control Regulation in 2009 and National Drought Control Planning in 2011. These policies not only define the responsibilities for drought control but also promote technical, physical, and financial policies to help farmers deal with drought. In addition, the establishment of an early warning and prevention information system at the national and local level also has been noticed by policymakers in China (Chen et al., 2014).

A pertinent question is whether the government's efforts on issuing adaptation polices significantly influence farmers' adaptive decisions and help them improve their adaptive capacity. Moreover, how is the information from the early warning and prevention system delivered to farmers? What are major policy supports for farmers to deal with extreme weather events? Have the early warning information system and various policy supports against extreme weather events improved adaptive capacity of farmers? In practice, what kinds of adaptive measures are taken by farmers to fight drought? In addition to adaptation policies, what other factors influence farmers' adaptive behavior? In recent years, a growing body of literature has analyzed the determinants of farmers' adaptive decisions, both qualitatively (Ju et al., 2008; Su et al., 2012; Sjögersten et al., 2013) and quantitatively (Deressa et al., 2009; Di Falco et al., 2011; Chen et al., 2014; Huang et al., 2014; Wang et al., 2014). However, most studies have focused on the effects of physical and socioeconomic factors while only a few studies have quantified the influence of some adaptation policies on farmers' adaptive behavior (e.g., Di Falco et al., 2011; Chen et al., 2014). Importantly, no study has analyzed farmers' adaptive behavior against drought in the NCP. Increasingly extreme weather events have turned the spotlight on the importance of effective measures taken by farmers not just in China but also in other developing countries (Mendelsohn et al., 2006; Seo and Mendelsohn, 2006).

The overall goal of this paper is to assess the effectiveness of major adaptation policies on farmers' adaptive decisions in the NCP. Specifically, we focus on two kinds of adaptation policies. The first policy is provision of early warning and prevention information against drought, and the second is provision of technical, physical and financial policy support. Not only do we focus on the provision status, but we also identify the effectiveness of provision channels and types of policy supports, respectively, that are used to implement the above mentioned adaptation policies. As revealed by Chen et al. (2014), the major adaptive measures taken by farmers are nonengineering measures, or farm management measures (such as adjusting crop varieties, changing seeding and/or harvesting dates, adjusting production inputs, or other management measures relevant to crop production). Therefore, this paper also focuses on farm management measures. Finally, adaptive farm management measures likely differ by crop. In this study we select wheat, the most important crop in the NCP, as the target crop.

To meet the above objectives, the rest of this paper is organized as follows. The next section briefly introduces the data used in this study. Section 3 discusses the farm management measures taken by farmers. Section 4 presents the results of the descriptive statistical analysis on the correlation among information provision, policy support and farm management measures taken by farmers against drought. Econometric analyses in Section 5 include the influence of information provision, policy supports and other factors on farmers' adaptive responses in terms of farm management measures. Section 6 concludes with policy implications.

\section{Data}

The data used in this study are based on a large-scale household and village survey conducted in nine provinces of China from the end of 2012 to the early 2013. These nine provinces include Hebei, Henan, Shandong, Jiangsu, Anhui and Jilin in northern China, and Jiangxi, Guangdong and Yunnan in southern China. Of these nine provinces, five provinces (Hebei, Henan, Shandong, Jiangsu and Anhui) are located in the NCP and therefore used in this study (Fig. 1). While the NCP also covers Beijing and Tianjin, wheat production in above five provinces accounted for $99 \%$ of wheat production in the NCP and 75\% of China's total wheat production in 2012 (NSBC, 2012).

During the survey, the following strategies were used for sample design and selection in each province. First, three counties in each province were randomly selected from those counties that met the following two conditions in the past three years (2010-2012): (i) had experienced a year with severe drought or flood (or disaster year); and (ii) had experienced a relatively normal weather year. A relatively normal year here is considered as a year when severe drought or flood did not occur at the county level. Many fewer farmers experience drought or flood in a relatively normal weather year (for convenience, the term normal year is used thereafter). By collecting data from one year with an extreme weather event and the other year having normal, we can identify the impact of extreme weather and differences in adaptation between extreme weather year and normal year. The selection of these counties is possible because there are about 100 counties in each province, and at least $20 \%$ of them experienced a severe drought and flood during the past three years.

Stratified random sampling was used to select three townships from each selected county and three villages from each township. Townships were stratified into three groups according to their rural water infrastructure: above average, average, or below average. Then one township from each of these three groups was randomly selected. The same approach was used to select three villages from each of the selected townships. Finally, ten farm households were randomly selected in each village, and in each farm household, two plots that were planted to major crops were chosen for the survey. In total, the samples in the five selected provinces included 2700 plots, 1350 households, and 135 villages in 15 counties. For more detailed sampling rules, please refer to Huang et al. (2014). Since our research focuses on how farmers' planting practices help wheat adapt to drought, we deleted questionnaires obtained in the flood counties and from households that did not plant wheat in the past three years. The final sample included 1626 plots and 870 households in 89 villages in 10 counties. The collected data for each plot included data for both a normal and a drought year.

While the household and village level survey covers a wide range of issues, our analysis used only data relevant to this study. For the household level surveys, we used the following data: (i) farm management measures taken by farmers at their plots to cope with drought, such as planting drought-resistant varieties, adjusting dates of seeding and/or harvesting, reseeding, enhancing irrigation intensity, and increasing production inputs (such as fertilizer, labor, and pesticide); (ii) household characteristics, such as farm size, number of family members, age, education and farming experience of household head, number of relatives, distance to the 


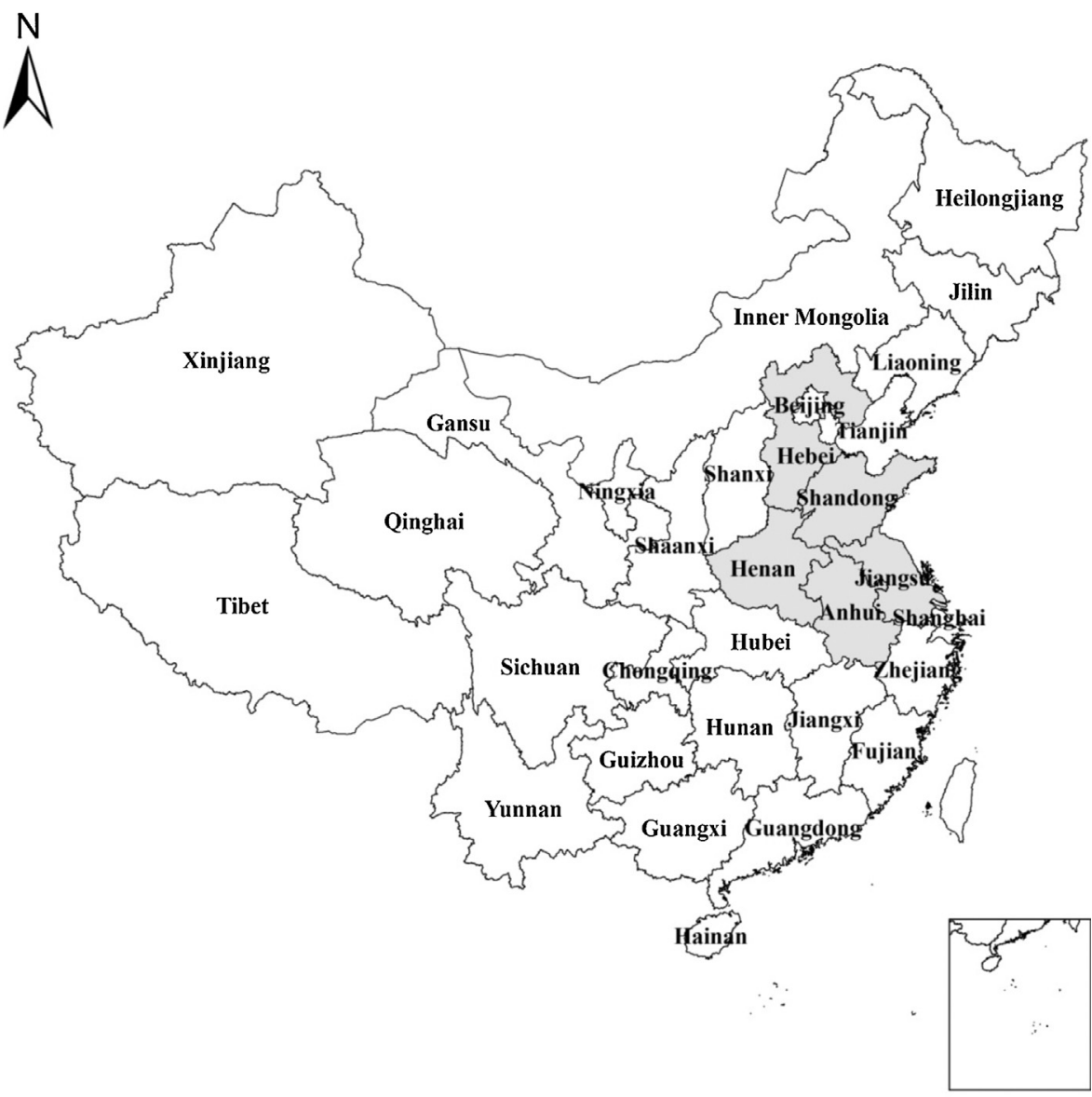

Fig. 1. Locations of five provinces in the North China Plain (NCP) in China.

nearest wholesale markets of agricultural products and distance to the nearest shops for agricultural production inputs; and (iii) plot characteristics such as soil type (loam, clay and sandy soil) and salinity characteristics, landform (plain or mountain), and distance to the nearest township road.

For the village level survey, we used mainly the following three kinds of data: (i) information on provision status of early warning and prevention information (whether or not the provision existed) and channels for its provision to villages (provision channels included TV, meeting, loudspeaker, documentation, cell phone text message, and face-to-face reminders); (ii) policies in terms of technical (such as sending extension workers to the field), financial (such as providing subsidies) and physical support (such as providing production inputs) from the government to help villages to cope with drought; (iii) condition of the irrigation infrastructure in the villages, such as numbers of tubewells, irrigation and drainage stations, branch and tertiary canals, and ponds. The descriptive statistics of the above data collected from the household and village level surveys are summarized in Table in the Appendix.

\section{Farm management measures taken by farmers against drought}

In the NCP, even in a normal year, farmers still need to implement some farm management measures to improve agricultural productivity. As an ecologically vulnerable region characterized by frequent drought, there is almost no absolutely normal year existing in the NCP. Therefore, it is not surprising to find that farmers took certain farm management measures to ensure agricultural
Table 1

Farm management measures taken by wheat farmers to cope with drought in the NCP.

\begin{tabular}{lcl}
\hline & Normal year & Drought year \\
\hline Adjusting dates of seeding or harvesting $^{\mathrm{a}}$ & 0.0 & 24.0 \\
Enhancing irrigation intensity $^{\mathrm{a}}$ & 0.0 & 19.8 \\
Reseeding $_{\text {Planting drought-resistant seed }}$ & 15.7 & 17.0 \\
Increasing production inputs $^{\mathrm{a}}$ & 8.7 & 9.3 \\
\hline
\end{tabular}

Source: Authors' survey.

a Relative to normal year.

production even in the normal year. For example, even in the normal year, $8.7 \%$ of sampled plots planted drought-resistant varieties and $13.7 \%$ of sampled plots reseeded to cope with drought and reduce production vulnerability.

However, we are most interested in how farmers change or strengthen their farm management practices to mitigate the potential negative impacts of a severe drought? Our results show that when faced with more severe droughts, farmers change their management practices or make adaptive responses to mitigate the impacts of the drought. The first line of response included adjusting the seeding and/or harvesting dates for wheat; indeed, $24 \%$ of sample wheat plots had adjusted seeding and/or harvesting dates (Table 1). Relative to the normal year, in the year with more severe drought, $11 \%$ of the sampled plots had advanced seeding date by 12 days, and $10 \%$ of the sampled plots had postponed seeding dates by 10 days. In addition, $8 \%$ and $6 \%$ of the sampled plots had advanced and postponed harvesting dates by 9 days and 7 days, respectively. 
Table 2

Provision of early warning and prevention information and policy support.

Share of villages (\%)

$$
\begin{aligned}
& \text { Early warning and prevention information } \\
& \text { Without provision } \\
& \text { With provision } \\
& \text { By type of provision channels } \\
& \text { - TV } \\
& \text { - Only one channel } \\
& \text { - Two or more channels } \\
& \text { - } \\
& \text { Policy support against drought } \\
& \text { Without policy support } \\
& \text { With policy support } \\
& \text { By type of policy support } \\
& \text { - Only technical support } \\
& \text { - Only physical support } \\
& \text { - Only financial support } \\
& \text { - Two or more support }
\end{aligned}
$$

Source: Authors' survey.

a Including TV (only TV or TV and other channels together).

b Only one of the following five kinds of channels: meeting, loudspeaker, document, cell phone text message or face-to-face reminders.

${ }^{c}$ Not including TV, any combination of the following five kinds of channels: meeting, loudspeaker, document, cell phone text message or face-to-face reminders.

Farmers also respond to drought by enhancing irrigation intensity (or increase irrigation times). Compared with the normal year, an additional $19.8 \%$ of the wheat plots increased irrigation intensity in the severe drought year (Table 1). As the region suffers from water shortages, the use of irrigation as an important measure to ensure agricultural productivity is notable. In our sample, $74 \%$ of the wheat plots were irrigated using either groundwater or surface water. Thus, the severe water shortage during drought years and the continued depletion of the groundwater and surface water mean that enhancing irrigation in the field will become an important adaptive measure for farmers to mitigate the negative impacts of drought. Farmers reseeded or planted drought-resistant seed even in the normal year, and these activities increased in more severe drought years; the percentage of reseeded plots increased from $15.7 \%$ to $17 \%$. Finally, some production inputs (such as fertilizer, labor and pesticide) also were found to have increased in the severe drought year, but only moderately (1.7\%).

\section{Information provision, policy support, and farm management measures against drought}

\subsection{Information provision and farm management measures taken by farmers}

The provision of early warning and prevention information is an important adaptive measure provided by the government to cope with drought. Our results show that $69 \%$ of the sampled villages used early warning information provided by the local government to cope with drought (Table 2). Information provision mainly emphasizes how farmers might prevent potential losses by informing them about the possible duration and severity of the forecasted drought and by reminding them about measures that they could take to reduce losses (Chen et al., 2014).

The provision of early warning and prevention information takes place via different channels (Table 2). This information can be provided to villages through media, such as television (TV), the most common medium in rural areas. Additionally, such information also can be provided in meetings organized by township or county officials who then release the information to village leaders and farmers. Issuing urgent disaster documents from higher to lower levels of government, texting messages to farmers' cell phones or educating farmers through loudspeakers or face-to-face

Table 3

Relationship between provision of early warning and prevention information and farm management measures taken by farmers.

\begin{tabular}{ll}
\hline & $\begin{array}{l}\text { Share of plots applying farm } \\
\text { management measures (\%) }\end{array}$ \\
\hline $\begin{array}{l}\text { Without provision } \\
\text { With provision }\end{array}$ & 30 \\
By type of provision channels & 41 \\
- TV & 41 \\
- Only one channel & 37 \\
- Two or more channels ${ }^{\mathrm{c}}$ & 42 \\
\hline Source: Authors' survey. & \\
a Including TV (only TV or TV and other channels together). \\
b Only one of the following five kinds of channels: meeting, loudspeaker, docu- \\
ment, cell phone text message or face-to-face reminders. \\
c Not including TV, any combination of the following five kinds of channels: meet- \\
ing, loudspeaker, document, cell phone text message or face-to-face reminders.
\end{tabular}

reminders are all possible channels for villages to receive such information. Our survey shows that TV is one of the most important channels for spreading early warning and prevention information, and $48 \%$ of the sampled villages received this information through this channel (Table 2). In contrast, $11 \%$ of the sampled villages were provided information only through the following four channels: meetings, loudspeakers, documentation, cell phone text messages, or face-to-face reminders. Finally, $10 \%$ of the sampled villages received information from more than two channels (excluding TV) (Table 2).

The farmers' adaptive responses against drought are closely related to information provision. When the villages were provided with this information, farmers implemented farm management measures to cope with drought for $41 \%$ of the plots (Table 3 ). This percentage is higher than that in the villages that were not provided this information (30\%). As expected, those villages that received the information service from two or more channels had the highest application of farm management measures (42\%).

\subsection{Policy support and farm management measures taken by farmers}

In addition to the provision of early warning and prevention information, the government also provides direct technical, physical, and financial policy support to enhance the adaptation capacity of local communities and farmers. With respect to technical support, its major pattern is to send extension staff and technology researchers to the fields to advise farmers on how they could apply new management practices (such as adjusting seeding and/or harvesting dates or using some new seed varieties) (Chen et al., 2014). The local government also provides farmers with materials (e.g., drought-resistant seeds, fertilizer, pesticide or other inputs) to help mitigate effects of drought; we call these physical supports. Financial support is provided directly to farmers through drought relief funds and subsidized loan. According to our survey, only $18 \%$ of the sampled villages obtained one or more kinds of policy support (Table 2). Specifically, 13\% of the villages obtained only one of three kinds of support. The number of sampled villages that obtained only financial support $(8 \%)$ is higher than other those that were provided one of the other two types of support (3\% for technical support and $2 \%$ for physical support). Five percent of the sampled villages obtained two or more kinds of policy support during the same period.

Provision of policy support is positively associated with farmers' adaptive responses to drought. The share of plots that applied farm management measures in villages getting policy support from the government was $44 \%$, higher than that of the villages that did not get such support (Table 4). Importantly, we found that farmers' 
Table 4

Relationship between policy support and farm management measures taken by farmers.

\begin{tabular}{ll}
\hline & $\begin{array}{l}\text { Share of plots applying farm } \\
\text { management measures (\%) }\end{array}$ \\
\hline Without policy support & 35 \\
With policy support & 44 \\
By type of policy support & \\
Only technical support & 35 \\
Only physical support & 44 \\
Only financial support & 41 \\
Two or more support & 61 \\
\hline
\end{tabular}

Sources: Authors' survey.

adaptive responses (or the share of plots applying farm management measures) were higher (61\% of the plots) when two or more kinds of policy support (combination of technical, physical and financial support) were provided to the villages. If only one of three kinds of support were provided to the village, the share of the plots applying farm management measures ranged from $35 \%$ to $44 \%$.

\section{Econometric model and estimation results}

\subsection{Specification of econometric models}

Since descriptive analysis does not control for the influence of other factors, it is difficult to separate the major factors influencing farmers' decisions on farm management measures against drought. To better quantify the influences of different factors on farmers' decisions, we specified the following econometric model, based on Chen et al. (2014), Di Falco et al. (2011) and Deressa et al. (2009).

$M_{i j k}=\alpha+\beta D_{k}+\delta I_{k}+\theta P_{k}+\gamma V_{k}+\varphi H_{j k}+\phi L_{i j k}+\eta R_{k}+\varepsilon_{i j k}$

In the above model, $M_{i j k}$ indicates whether the farmer of plot $i$ in household $j$ in village $k$ applied farm management measures against drought, with a value of 1 if the plot applied the farm management measures (such as adjusting dates of seeding or harvesting, enhancing irrigation intensity, planting drought-resistant varieties or increasing production inputs) or zero otherwise. $D_{k}$ is a dummy variable measuring whether the severe drought occurred ( $1=$ yes; $0=$ no). $I_{k}$ represents the early warning and prevention information service at the village level, measured in the following two alternative ways: (i) a dummy variable on whether the early warning and prevention information was provided ( $1=$ yes; $0=$ no); or (ii) three dummy variables $(1=$ yes; $0=$ no) on the channels of information service, namely TV channel, only one channel, and two or more channels as discussed in the previous section. $P_{k}$ is policy support and is measured in the following two alternative ways at the village level: (i) a dummy variable on the provision of policy support ( 1 =yes; $0=$ no); or (ii) four dummy variables ( $1=$ yes; $0=$ no) on the types of policy support as discussed in Table 4.

In addition to the above three sets of explanatory variables that are particularly interesting, we also include a set of control variables on village infrastructure $\left(V_{k}\right)$, characteristics of households $\left(H_{j k},\right)$, plots $\left(L_{i j k}\right)$, and a set of provincial dummy variables $\left(R_{i j k}\right.$, $)$ that might affect the application of adaptive measures by individual households. Specifically, $V_{k}$ includes four variables. They are the number of tubewells, the number of irrigation and drainage stations, the number of branch and tertiary canals, and whether or not there was a water pond in the village. $H_{j k}$ includes eight variables on the household characteristics. They are farm size (ha), number of family members, age (year), education (year), farming experience (years) of household head, number of relatives within three generations, distance to the nearest wholesale market of agricultural products $(\mathrm{km})$, and distance to the nearest shop selling agricultural inputs $(\mathrm{km}) . L_{i j k}$ includes five plot characteristics, represented by two dummy variables for different soil types (loam and clay soil), one saline dummy variable ( $1=$ yes; $0=$ no), one land type variable ( 1 for plain and 0 for mountain), and one variable on the distance to the nearest township road (km). $R_{i j k}$, is a set of provincial dummy variables that control for those factors and that differ by province but that do not change over time. In the model, $\alpha, \beta, \delta, \theta$, $\gamma, \varphi, \phi, \eta$ are parameters to be estimated. $\varepsilon_{n i j}$ is random error term and assumed to be subjected to independent identical distribution.

\subsection{Estimation results}

The econometric model presented above is estimated in two alternative specifications due to two alternative measurements of the policy variables. The estimation results of both specifications (Model 1 and Model 2) are presented in Table 5.

The estimation results for the two models show that both models perform well. The likelihood-ratio statistics for the two models are all significant at the $1 \%$ level and pass the Chi-squared test (Table 5). The goodness of fit measures (the Pseudo $R^{2}$ ) ranges from 0.132 to 0.134 , which is not low for cross-sectional household data, in particular for a binary response model.

Importantly, the signs of most interested variables are statistically significant and consistent with our expectation. For example, the sign of the drought event coefficient is positive and statistically significant at the $1 \%$ level in both models, which implies the importance of drought event on farmers' adaptive behavior. The provision of information is positive and statistically significant, and the variable representing two or more information channels also is positive and statistically significant. Therefore, information provision (particularly through two or more channels can play significant impacts on farmers' adaptive behavior. The variable representing policy support and variables representing support types (through technical or two or more types) are positive and statistically significant, indicating the importance of policy support on influencing farmers' adaptive behavior.

Furthermore, the sign of many village, household, and plot level control variables are consistent with our expectations, and about half of them are statistically significant. For example, in both two models, the sign of the coefficient on pond is positive and statistically significant, which implies that, after keeping all other factors constant, farmers are more likely to apply farm management measures in those villages that have water ponds. The results also indicate that larger farms are more capable at applying adaptive measures. Younger farmers and farmers with richer farming experiences and better social networks (due to having more relatives) are more likely to apply adaptive measures against drought. Such results are also consistent with the findings of some other studies, such as Chen et al. (2014) and Deressa et al. (2009). Moreover, the results also indicate that adaptive measures on farm management are more likely to be implemented on plain farmlands than on hilly, sloped or terraced farmlands. One possible reason for this result could be the ease of applying farm management measures in plain farmlands.

\subsection{Discussion for major results}

As expected, when faced with drought, farmers did make adaptive responses to reduce their vulnerability to drought disaster. The sign of the drought event coefficient is positive and statistically significant at the $1 \%$ level in both models (Table 5 ). The estimated marginal effect ( 0.2799 in model 1 and 0.2827 in model 2; Table 5) suggest that, after controlling for the impacts of other factors in the model, when wheat is shocked by a severe drought, compared with normal year, the probability of farmers to adapt to drought through applying farm management measures increases by about $28 \%$. 
Table 5

Determinants of farm management measures taken by farmers against drought: Probit Econometric model.

\begin{tabular}{|c|c|c|}
\hline & Model 1 & Model 2 \\
\hline Drought year $(1=$ yes; $0=$ no $)$ & $0.2799^{* * *}(15.88)$ & $0.2827^{* * *}(15.66)$ \\
\hline $\begin{array}{l}\text { Provision of early warning and } \\
\text { prevention }(1=\text { yes; } 0=\text { no })\end{array}$ & $0.0340^{*}(1.65)$ & \\
\hline \multicolumn{3}{|c|}{ Provision channels of early warning and prevention information } \\
\hline $\mathrm{TV}(1=$ yes; $0=$ no $)$ & & $0.0291(1.33)$ \\
\hline Only one channel ( $1=$ yes; $0=$ no $)$ & & $0.0062(0.16)$ \\
\hline $\begin{array}{l}\text { Two or more channels }(1=\text { yes; } \\
0=\text { no })\end{array}$ & & $0.0643^{*}(1.84)$ \\
\hline $\begin{array}{l}\text { Policy support against drought } \\
\qquad(1=\text { yes; } 0=\text { no })\end{array}$ & $0.0740^{* * *}(3.07)$ & \\
\hline \multicolumn{3}{|l|}{ Types of policy support against drought } \\
\hline $\begin{array}{l}\text { Only technical support }(1=\text { yes; } \\
0=\text { no) }\end{array}$ & & $0.0191(0.39)$ \\
\hline $\begin{array}{l}\text { Only physical support }(1=\text { yes; } \\
0=\text { no) }\end{array}$ & & $0.2122^{* * *}(2.95)$ \\
\hline $\begin{array}{l}\text { Only financial support }(1 \text { = yes; } \\
\quad 0=\text { no })\end{array}$ & & $0.0530(1.60)$ \\
\hline $\begin{array}{l}\text { Two or more support }(1=\text { yes; } \\
\quad 0=\text { no) }\end{array}$ & & $0.1354^{* * *}(0.0472)$ \\
\hline \multicolumn{3}{|l|}{ Village irrigation infrastructure } \\
\hline Number of tubewells & $-0.0011^{* *}(2.54)$ & $-0.0012^{* * *}(2.62)$ \\
\hline $\begin{array}{l}\text { Number of irrigation and drainage } \\
\text { stations }\end{array}$ & $0.0081(0.30)$ & $0.0167(0.62)$ \\
\hline $\begin{array}{l}\text { Number of branch and tertiary } \\
\text { canals }\end{array}$ & $-0.0018(1.09)$ & $-0.0019(1.11)$ \\
\hline Having pond $(1=$ yes; $0=$ no $)$ & $0.0482^{*}(1.78)$ & $0.0677^{* *}(2.38)$ \\
\hline \multicolumn{3}{|l|}{ Household characteristics } \\
\hline Farm size (ha) & $0.0247(1.64)$ & $0.0256^{*}(1.70)$ \\
\hline Family member (persons) & $0.0022(0.77)$ & $0.0027(0.66)$ \\
\hline Age of household head (years) & $-0.0062^{* * *}(3.55)$ & $-0.0064^{* * *}(3.66)$ \\
\hline $\begin{array}{l}\text { Education of household head } \\
\text { (years) }\end{array}$ & $0.0055^{* * *}(0.77)$ & $0.0056^{* * *}(0.66)$ \\
\hline $\begin{array}{l}\text { Farming experience of household } \\
\text { head (years) }\end{array}$ & $0.0023(3.40)$ & $0.0020(3.41)$ \\
\hline $\begin{array}{l}\text { Number of relatives within three } \\
\text { generations }\end{array}$ & $0.0075^{* * *}(4.41)$ & $0.0076^{* * *}(4.45)$ \\
\hline $\begin{array}{l}\text { Distance to the nearest wholesale } \\
\text { market }(\mathrm{km})\end{array}$ & $0.0012(1.35)$ & $0.0014(1.55)$ \\
\hline $\begin{array}{l}\text { Distance to the nearest shop } \\
\text { selling agricultural inputs (km) }\end{array}$ & $-0.0004(0.08)$ & $0.0000(0.07)$ \\
\hline \multicolumn{3}{|l|}{ Plot characteristics } \\
\hline Loam ( 1 = loam; 0 = other $)$ & $-0.0307(1.24)$ & $-0.0320(1.29)$ \\
\hline Clay $(1=$ clay; $0=$ other $)$ & $-0.0219(0.88)$ & $-0.0267(1.06)$ \\
\hline Saline $(1=$ yes; $0=$ no $)$ & $0.0670^{* *}(2.29)$ & $0.0647^{* *}(2.21)$ \\
\hline Land type ( 1 = Plain; 0 = Mountain $)$ & $0.1371^{* *}(1.93)$ & $0.1419^{* *}(2.00)$ \\
\hline $\begin{array}{l}\text { Distance to the nearest township } \\
\operatorname{road}(\mathrm{km})\end{array}$ & $0.0184(1.20)$ & $0.0186(1.21)$ \\
\hline Province dummies & Not report & Not report \\
\hline Observations & 3252 & 3252 \\
\hline LR chi $^{2}$ & 565 & 577 \\
\hline Pseudo $R^{2}$ & 0.132 & 0.134 \\
\hline
\end{tabular}

Note:

* Significant at the 10 percent level, respectively and $z$-value are in parentheses. ${ }^{* *}$ Significant at the 5 percent level, respectively and $z$-value are in parentheses.

*** Significant at the 1 percent level, respectively and $z$-value are in parentheses.

Importantly, the estimation results reveal that providing early warnings and prevention information significantly promotes the application of adaptive measures. The estimated coefficient of the variable that represents the provision of information is positive and statistically significant (Model 1, Table 5). The result demonstrates that providing early warning and prevention information plays a significant role in helping farmers decide whether they should apply adaptive measures when they face a drought. According to results on the marginal effects ( 0.034 ), if local governments provide information regarding drought, the possibility of farmers applying farm management measures can increase by $3.4 \%$.

However, the estimation results also reveal that the effectiveness of providing early warnings and prevention information differs largely by the channel of delivery (Model 2 , Table 5 ). The estimated coefficient on providing information through two or more channels (combinations of meetings, loudspeakers, documentation, cell phone text messages and, face-to-face reminders) is positive and statistically significant (row 5). However, although the coefficients for only one channel (only one of the following, excluding TV: meetings, loudspeakers, documentation, cell phone text messages, and face-to-face reminders) and TV alone are positive, but are not statistically significant. It implies that provision of information intended to promote the application of farm management measures against drought is effective only if several channels are employed simultaneously. Based on the marginal effect estimation (0.064), information provision through two or more channels can increase the possibility of farmers implementing adaptive measures by $6.4 \%$. Interestingly, although TV is the most common channel for information provision, it does not play a significant role in promoting the implementation of adaptive measures. This result possibly indicates that farmers do not pay enough attention to the information provided through TV.

Furthermore, the estimation results show that offering policy support significantly facilitates farmers in applying adaptive measures against drought. The estimated coefficient for the provision of policy support variable is positive and statistically significant (Model 1 in Table 5). That is, during times of severe drought, if the government can provide policy supports by assisting farmers to relax some of their constraints either on technical, physical or financial aspects, their probability to adapt to drought through applying farm management measures can increase by $7.4 \%$.

Similarly, we also found that the impacts on farmers to apply adaptive measures against drought differ largely by type of policy support. Significant impacts are found for policy support only through physical support (Model 2, Table 5). The estimated coefficient for only physical support is positive and statistically significant at the $1 \%$ level, indicating that such support can increase the probability of farmers applying adaptive measures by nearly $21 \%$. Interestingly, no statistically significant impacts of technical or financial support on farmers' adaptation are found in our study. While we have no good explanation for this insignificant impact, the quality of technical extension or the amount of financial subsidies for drought might need attention. As expected, the estimated marginal effect of the variable for two or more policy supports is statistically significant, and its magnitude $(0.1354)$ is between the impacts of physical support (0.2122) and the other two policy supports. This is because the variable also includes the technical and financial supports that have relatively lower impacts than the physical policy support variable. The overall results indicate that providing policy supports can create larger impacts on farmers' adaptive decisions than information provision.

\section{Concluding remarks}

This study examined how farmers have made adaptive responses against drought and assessed the effectiveness of adaptation policies on farmers' decisions in the NCP. The data come from one large field survey in five provinces in the NCP. The results show that even in a normal year, farmers growing wheat still need to apply some farm management measures to improve agricultural productivity. Part of the reason could be that these farm management measures can improve wheat productivity. Also some wheat plots in certain villages might suffer severe drought in relatively normal years as the size of a county in the NCP is quite big. Interestingly, when faced with more severe droughts, farmers tended to change their management practices. The results show that the major changes in farm management practices included adjusting seeding and/or harvesting dates, enhancing irrigation intensity, and reseeding or planting drought-resistant seed. 
Quantitative analysis based on econometric modeling reveals that the adaptation policies do have impacts on farmers' adaptive responses to drought through applying farm management measures. Specifically, our results show that keeping other factors constant, the provision of early warning and prevention information can increase the probability of farmers applying farm management measures by $3.4 \%$. If the information is provided through multiple channels simultaneously (such as combinations of meetings, loudspeakers, documentation, cell phone text messages, and face-to-face reminders), the probability of applying adaptive measures increases by more (7.4\%). In addition, the provision of policy support creates even larger impacts on farmers' adaptive decisions; if local governments provide policy support against drought, on average, the probability of farmers applying farm management measures increases by $7.4 \%$. The most effective policy is physical support, which can increase the probability of applying adaptive measures by $21 \%$.

The results of this study have several policy implications. First, there is room for the government to improve its early warning and prevention information system for local villages and farmers. In our study area, about one third of the rural villages in the NCP were not provided with this information service. Second, there is considerable room for expanding direct policy support, since it can play an even larger role in improving farmers' adaptive capacity. In our sample sites, the percentage of villages with access to policy support was low; only $18 \%$ of the sampled villages enjoyed one or more kinds of policy support. The influence of policy support on farmers' adaptive responses is larger than provision of information. Third, our results also imply that the effectiveness of policies differs largely among different types of policy support. There should be priorities for government's efforts and expenditures. Of course, different policy supports also should consider their costs and benefits, which is an important issue that needs further study. Fourth, enhancing the adaptation capacity of smaller farms and improving social networks of all farmers are particularly important for climate adaption policies. Last but not least, we believe that improving farmers' adaptive capacity against drought is not only relevant to sustainable development in agricultural production, but also relevant to the overall healthy development of the ecological system in the NCP. Agricultural production and the associated agro-ecosystem are important components of the ecological system. Improving adaptation capacity in agriculture and improving its productivity can also partially release increasing land and water pressure from crop production and therefore indirectly contribute to sustainable development of the ecological system in the NCP.

\section{Acknowledgements}

We acknowledge financial support from the Ministry of Science and Technology (2012CB955700), the National Natural Sciences Foundation of China (71161140351, 70925001), International Development Research Center (107093-001) and Australian Center for International Agricultural Research (ADP/2010/070).

\section{Appendix A.}

Table A1

Descriptive statistics of major variables in drought area of NCP.

\begin{tabular}{lcc}
\hline & Mean & Std. dev. \\
\hline Farming management adaptation & 0.372 & 0.483 \\
$\begin{array}{l}\text { (1= applying; } 0 \text { = no applying) } \\
\text { Drought year }(1=\text { yes; } 0=\text { no) }\end{array}$ & & \\
Provision of early warning and prevention & 0.500 & 0.500 \\
& & 0.4661
\end{tabular}

Provision of early warning and prevention

0.466
Table A1 (Continued)

\begin{tabular}{|c|c|c|}
\hline & Mean & Std. dev. \\
\hline \multicolumn{3}{|c|}{ Provision channels of early warning and prevention information } \\
\hline $\mathrm{TV}(1=$ yes; $0=$ no $)$ & 0.482 & 0.500 \\
\hline Only one channel $(1=$ yes; $0=$ no $)$ & 0.107 & 0.297 \\
\hline Two or more channels $(1=$ yes; $0=$ no $)$ & 0.103 & 0.307 \\
\hline Policy support against drought $(1=$ yes; $0=$ no $)$ & 0.191 & 0.394 \\
\hline \multicolumn{3}{|l|}{ Types of policy support against drought } \\
\hline Only technical support $(1=$ yes; $0=$ no $)$ & 0.034 & 0.181 \\
\hline Only physical support $(1=$ yes; $0=$ no $)$ & 0.020 & 0.143 \\
\hline Only financial support $(1=$ yes; $0=$ no $)$ & 0.083 & 0.277 \\
\hline Two or more support $(1=$ yes; $0=$ no $)$ & 0.052 & 0.223 \\
\hline \multicolumn{3}{|l|}{ Village irrigation infrastructure } \\
\hline Number of tubewells & 57.83 & 72.629 \\
\hline Number of irrigation and drainage stations & 0.332 & 0.969 \\
\hline Number of branch and tertiary canals & 3.601 & 9.001 \\
\hline Having pond $(1=$ yes; $0=$ no $)$ & 0.350 & 0.471 \\
\hline \multicolumn{3}{|l|}{ Household characteristics } \\
\hline Farm size (ha) & 0.583 & 0.635 \\
\hline Family member (person) & 4.709 & 2.000 \\
\hline Age of household head (year) & 54.241 & 10.392 \\
\hline Education of household head (year) & 6.977 & 3.152 \\
\hline Farming experience of household head (year) & 34.843 & 11.286 \\
\hline Number of relatives within three generations & 12.833 & 5.396 \\
\hline $\begin{array}{l}\text { Distance to the nearest wholesale market } \\
(\mathrm{km})\end{array}$ & 8.365 & 10.121 \\
\hline $\begin{array}{l}\text { Distance to the nearest shop selling } \\
\text { agricultural inputs }(\mathrm{km})\end{array}$ & 1.467 & 1.705 \\
\hline \multicolumn{3}{|l|}{ Plot characteristics } \\
\hline Loam ( 1 = loam; 0 = other $)$ & 0.363 & 0.481 \\
\hline Clay $(1=$ clay; $0=$ other $)$ & 0.373 & 0.484 \\
\hline Saline $(1=$ yes; $0=$ no $)$ & 0.109 & 0.312 \\
\hline Land type (1 = Plain; 0 = Mountain) & 0.985 & 0.123 \\
\hline Distance to the nearest township road (km) & 0.319 & 0.676 \\
\hline Plot sample & \multicolumn{2}{|c|}{3252} \\
\hline
\end{tabular}

Source: authors' survey.

\section{References}

Chen, H., Wang, J., Huang, J., 2014. Policy support, social capital, and farmers' adaptation to drought in China. Global Environ. Change 24, 193-202.

Dai, Ai., 2011. Drought under global warming: a review. Wiley Interdiscipl. Rev.: Clim. Change 2 (January/February), 45-66, http://dx.doi.org/10.1002/wcc.81.

Deressa, T.T., Hassan, R.M., Ringler, C., Alemu, T., Yesuf, M., 2009. Determinants of farmers' choice of adaptation methods to climate change in the Nile Basin of Ethiopia. Global Environ. Change 19 (2), 248-255.

Di Falco, S., Veronesi, M., Yesuf, M., 2011. Does adaptation provide food security? A micro perspective from Ethiopia. American Journal of Agricultural Economics 93 (3), 829-846

Huang, J., Jiang, J., Wang, J., Hou, L., 2014. Crop diversification in coping with extreme weather events in China. J. Integr. Agric. 13, 677-686.

IPCC (Intergovernmental Panel on Climate Change), 2007. Summary for policymakers. In: Climate Change 2007: Synthesis Report. Contribution of Working Groups I, II and III to the Fourth Assessment Report of the Intergovernmental Panel on Climate Change. Cambridge University Press, London.

IPCC (Intergovernmental Panel on Climate Change), 2012. Summary for policymakers. In: Food Security and Food Production Systems. A Special Report of Working Groups I and II of the Intergovernmental Panel on Climate Change. Cambridge University Press, London.

Ju, H., Conway, D., Li, Y., Harvey, A., Lin, E., Calsamiglia-Mendlewicz, S., 2008. Adaptation Framework and Strategy. Part 2: Application of the Adaptation Framework: A Case Study of Ningxia, Northwest China. AEA Group, UK.

Kantolic, A.G., Mercau, J.L., Slafer, G.A., Sadras, V.O., 2007. Simulated yield advantages of extending post-flowering development at the expense of a shorter pre-flowering development in soybean. Field Crops Res. 101, 321-330.

Mendelsohn, R., Dinar, A., Williams, L., 2006. The distributional impact of climate change on rich and poor Countries. Environ. Dev. Econ. 11, 1-20.

Mishra, A.K., Singh, V.P., 2010, September. A review of drought concepts. J. Hydrol. $391(1-2), 202-216$.

MWR (Ministry of Water Resources, P.R. China), 2009. Bulletin of Flood and Drought Disaster in China 2012. China Water Power Press, Beijing.

MWR (Ministry of Water Resources, P.R. China), 2012. Bulletin of Flood and Drought Disaster in China 2012. China Water Power Press, Beijing.

NDRC (The National Development and Reform Commission, P.R. China), 2007. China's Policies and Actions for Addressing Climate Change. The National Development and Reform Commission, Beijing.

NDRC (The National Development and Reform Commission, P.R. China), 2012. China National Plan for Coping with Climate Change. The National Development and Reform Commission, Beijing. 
NSBC (National Statistical Bureau of China, P.R. China), 2012. China Statistical Yearbook 2012. China Statistical Press, Beijing.

Seo, S.N., Mendelsohn, R., 2006. Climate change adaptation in Africa: a microeconomic analysis of livestock choice. In: CEEPA Discussion Paper No. 19. University of Pretoria, Pretoria.

Sjögersten, S., Atkin, C., Clarke, M.L., Mooney, S.J., Wu, B., West, H.M., 2013. Responses to climate change and farming policies by rural communities in northern China: a report on field observation and farmers' perception in dry land north Shaanxi and Ningxia. Land Use Policy 32, 125-133.

Su, Y., Xu, J., Wilkes, A., Lu, J., Li, Q., Fu, Y., Ma, X., Grumbine, R.E., 2012. Coping with climate-induced water stresses through time and space in the mountains of Southwest China. Reg. Environ. Change 12 (4), 855-866.

Thomson, A.M., Izaurralde, R.C., Rosenberg, N.J., He, X., 2006. Climate change impacts on agriculture and soil carbon sequestration potential in the Huang-Hai Plain of China. Agric. Ecosyst. Environ. 114 (2), 195-209.

Tian, Z., Zhong, H., Sun, L., Fischer, G., van Velthuizen, H., Liang, Z., 2014. Improving performance of Agro-Ecological Zone (AEZ) modeling by cross-scale model coupling: An application to japonica rice production in Northeast China. Ecol. Model. http://dx.doi.org/10.1016/j.ecolmodel.2013.11.020

Wang, Y., Huang, J., Wang, J., 2014. Household and community assets and farmers adaptation to extreme weather event: the case of drought in China. J. Integr. Agric. 13, 687-697.

World Bank, 2010. Economics of Adaptation to Climate Change: Synthesis Report, Available at: http://climatechange.worldbank.org/sites/default/files/ documents/EACCSynthesisReport.pdf

Xia, J., Liu, M., Jia, S., Song, X., Luo, Y., Zhang, S., 2004. Water security problem and research perspective in North China. J. Nat. Resour. 19 (5), 550-560.

Xiao, D., Tao, F., 2014. Contributions of cultivars, management and climate change to winter wheat yield in the North China Plain in the past three decades. Eur. J. Agron. 52, 112-122.

Zhang, B., Zhang, N., Zhang, Y., 2011. Performance assessment of agricultural adaptive measures to climate change. J. Agrotech. Econ. 7, 43-49. 